\title{
Significant Role of Viruses in Oral Squamous Cell Carcinoma Patients: A Review
}

\author{
Haya Muhammad ${ }^{1 *}$ and Shumaila Yonous ${ }^{2}$ \\ ${ }^{1}$ Karachi Medical and Dental College, Ziauddin medical university, Pakistan \\ ${ }^{2}$ Liaquat University of Medical and Health Sciences, Pakistan \\ *Corresponding author: Haya Muhammad, Ziauddin medical university, Pakistan
}

Received: 此 October 24, 2019

Published: 鴜 November 08, 2019

\begin{abstract}
Oral cancers are considered as the 6th most common predominant cancers in males. Some of the etiological components include viruses, alcohol and tobacco. Most common viruses include Hepatitis C virus, Epstein-Barr virus, Herpes simplex virus (HSV) and human papilloma virus (HPV). No doubt, the role of viruses is inevitable in progression and initiation of OSCC (Oral Squamous Cell Carcinoma). Rapid detection of these viruses can result in prevention and early treatment so that disease will not be progressed further.
\end{abstract}

Keywords: Oral Squamous Cell Carcinoma; Oral cancer; Herpes simplex virus; Hepatitis C

\section{Introduction}

OSCC (Oral Squamous Cell Carcinoma) is known to be the $6^{\text {th }}$ most common cancer throughout the whole world. The disease is widespread between smokers in comparison with non-smokers [1]. Research shows that there have been seven times more smokers which have been suffered with oral cancer as compared to non-smokers [2,3]. OSCC is a disease predominant in males but the recent cancer ratio depicts that it is found in females as well. Oral cancers occur at the age of 40 years and above [4-8]. Typically, the disease occurs in floor of mouth and tongue [9-13].

Oral cancer is a multi-step procedure in pathogenesis which leads to normal regulatory pathways disruption that regulate normalized cellular roles including cell death, differentiation and cell division $[14,15]$. Even though chemical carcinogens such as alcohol and tobacco have been the main etiology. They tend to participate in producing mutations in P53 suppresser genes which lead to tumour progression and initiation. Numerous viruses cause alteration in DNA coding and oral epithelial which result in oral carcinomas [16].

\section{Virus Found In Oral Squamous Cell Carcinoma Human Papillomavirus (HPV)}

HPV (Human papilloma virus) belongs to the family of Papovaviridae, un-wrapped dual standard spherical DNA viruses
[17]. They cause infections and particularly target basal cell of epithelium. Typically, HPV 6,11,16 and 18 are found in cancer epithelial cells [18]. Research indicates that prenatal transmission and oral sex cause infection [19].

The protein of HPV is comprised of a non-structural protein (genes encode E1-E7) and structural protein (late genes encodes L1-L2). Tumour transcription and replication transformation is regulated by early protein and final stages of viral cycle is carried out by late genes. HPV consisting of lower risk result in warts whereas HPV having high risk can cause malignant lesions $[17,20,21,22,23]$. P53 tumour suppressor gene (TP53) is degraded by the early protein E6 [24]. Q1 transition to S phase is regulated by TP53 in cell cycle [25]. Furthermore, this leads to damaging DNA, proliferation, increased cell and inadequacies can cause malignant transformation [26].

\section{Herpes Simplex Virus (HSV)}

HSV1 and HSV2 (Herpes simplex virus) cause infection to genital, ocular and oral areas. They stimulate the cellular protein expression and induce shock proteins [27]. These infections cause cell RNA and cell protein formation. Mechanism of Shut off becomes activated which is fundamentally an area of genome mtr1 of HSV1 and mtr2 of HSV2 respectively. Typically, there are two phases found. Phase 1 is more linked with viral activity which is followed 
right after infections [28]. Phase 2 requires expressions of viral genes, causes cell transformation and removes synthesis of host protein [29].

\section{Hepatitis C virus (HCV)}

Johnson exposed one of the possible contributions of Hepatitis $\mathrm{C}$ virus in oral cavity besides liver which causes genetic factor mutation of cells [30]. Hepatitis C virus is a packed and single strand RNA virus which is infected by detoxification of humanoid factor VIII (Cho et al.) [31]. Viral poly protein breakdown by translation of RNA results in capsid formation, viral proteases (NS2, NS3) and glycoproteins (E1, E2) which seem essential for malignancy and replication of RNA [32].

\section{Epstein-Bar Virus (EBV)}

EBV virus is comprised of dual stuck DNA genome which encodes 90 proteins with 172,000 base pairs. The latent proteins of EBV are LMP2 and LMP1 [33]. LMP1 works in B cell destruction and cell transformation. LMP1 with various groups of carboxyl is attracted to act on TRAFs (Tumour Necrosis Factor Receptor) [3335]. P38, jun, NF-JB present higher activity in LMP1 due to this interaction representing B cells and epithelial cells [36-38]. It helps to activate apoptotic genetic factors such as fibroblast growth factor (FGF) and metalloprotinease-9 (MMP-9). LMP2 mimics signals of B cell receptor (P13K/AKT pathways) which results in abnormal cell development [39].

\section{Conclusion}

Oral cancer increases the risk of infections and causes immune suppression. Contact of viruses in people can be a causative component for progression and initiation of disease. Additional studies on viruses will work as a supporting tool for new therapies, diagnosis and early examinations.

\section{References}

1. Moore SR, Johnson NW, Pierce AM, Wilson (2000) “The epidemiology of mouth cancer: a review of global incidence". Oral Disease 6(2): 65-74.

2. Poveda Roda R, Bagan JV, Jimenez Soriano Y, Margaix Munoz M, Sarrion Perez G (2010) "Changes in smoking habit among patients with a history of oral squamous cell carcinoma (OSCC)". Med Oral Patol Oral Cir Bucal 15(5): 721-726.

3. Nozad-Mojaver Y, Mirzaee M, Jafarzadeh A (2009) "Synergistic effects of cigarette smoke and saliva”. Med Oral Patol Oral Cir Bucal 14(5): 217221.

4. Prince S, Bailey BM (1999) “Squamous carcinoma of the tongue: review”. Br J Oral Maxillofac Surg 37(3): 164-174.

5. McGregor GI, Davis N, Robins RE (1983) "Squamous cell carcinoma of the tongue and lower oral cavity in patients under 40 years of age". American Journal of Surgery 146(1): 88-92.

6. Davidson B (2001) “Epidemiology and Etiology” In: Shah J, Cancer of the head and neck. American Cancer Society atlas of clinical oncology 1-18.

7. Callery CD, Spiro RH, Strong EW (1984) "Changing trends in the management of squamous carcinoma of the tongue". American Journal of Surgery 148(4): 449-454.

8. Scully C, Bagan J (2009) "Oral squamous cell carcinoma overview”. Oral Oncology 45(4-5): 301-308.
9. Hirata RM, Jaques DA, Chambers RG, Tuttle JR, Mahoney WD (1975) "Carcinoma of the oral cavity. An analysis of cases". Annals of Surgery 182(2): 98-103.

10. Oliver AJ, Helfrick JF, Gard D (1996) "Primary oral Squamous cell carcinoma: a review of 92 cases". J Oral Maxillofac Surg 54(8): 949-954.

11. Mashberg A, Merletti F, Bofetta P, Gandolfo S, Oxello F et al. (1989) "Appearance, site of occurrence, and physical and clinical characteristics of oral carcinoma in Torino, Italy". Cancer 63(12): 2522- 2527.

12. Jovanovic A, Schulten EA, Kostense PJ, Snow GB, Vanderwal I (1993) "Tobacco and alcohol related to the anatomical site of oral squamous cell carcinoma". Journal of Oral Pathology and Medicine 22(10): 459-462.

13. Brandizzi D, Gondolfo M, Velazco ML, Cabrini RL, Lanfranchi HE (2008) "Clinical features and evolution of oral cancer: a study of 274 cases in Buenos Aires, Argentina". Med Oral Patol Oral Cir Bucal 13(9): 544-548.

14. Ankathil R, Mathew A, Joseph F, Nair MK (1996) Is oral cancer susceptibility inherited? Eur J Cancer B Oral Oncol 32B(1): 63-67.

15. Je Vries S, Eeles R, Goldgar D, RA Hern, JM Henk, et al. (1999) The role of genetic factors in predisposition to squamous cell cancer of the head and neck. Br J Cancer 79(5-6):865-867.

16. Scully C (1993) Oncogenes, tumour suppressers and viruses in oral squamous carcinoma. J Oral Pathol Med 22(8): 337-347.

17. Yabe Y, Sadakane H, Isono H (1979) “Connection between capsomeres in human papilloma virus.” Virology 96(2): 547-552.

18. Ragin CCR, Modugno F, Gollin SM (2007) "The epidemiology and risk factors of head and neck cancer: a focus on human papillomavirus". J Dent Res 86(2): 104-114.

19. Gissmann L, Pfister H, Zur Hausen H (1977) “Human papilloma viruses (HPV): characterization of four different isolates." Virology vol 76(2): 569-580.

20.Syrjanen S (2010) "Current concepts on human papillomavirus infections in children." APMIS 118(6-7): 494-509.

21. Danos O, Katinka M, Yaniv M (1982) "Human papillomavirus 1a complete DNA sequence: a novel type of genome organization among papovaviridae". EMBO Journal 1(2): 231-236.

22. Schwarz E, Durst M, Demankowski C, Lattermann O, Zech R, et al. (1983) "DNA sequence and genome organization of genital human papillomavirus type 6b." The EMBO Journal 2(12): 2341-2348.

23. Kremsdorf D, Favre M, Jablonska S, Obalek S, Rueda LA, et al. (1984) "Molecular cloning and characterization of the genomes of nine newly recognized human papillomavirus types associated with epidermodysplasia verruciformis." Journal of Virology 52(3): 10131018.

24. Seedorf K, Krammer G, Durst M, Suhai S, Rowekamp WG (1985) “Human papillomavirus type 16 DNA sequence." Virology vol 145(1): 181-185.

25. Scheffner M, Whitaker NJ (2003) "Human papillomavirus-induced carcinogenesis and the ubiquitin-proteasome system." Seminars in Cancer Biology 13(1): 59-67.

26. Scheffner M, Werness BA, Huibregtse JM, Levine AJ, Howley PM (1990) "The E6 oncoprotein encoded by human papillomavirus types 16 and 18 promotes the degradation of p53." Cell 63(6): 1129-1136.

27. Filion M, Skup D, Suh M (1988) "Specific induction of cellular gene transcription in herpes simplex virus type-2-transformed cells." Journal of General Virology 69(8): 2011-2019.

28. Kwong AD, Frenkel N (1987) "Herpes simplex virus-infected cells contain a function(s) that destabilizes both host and viral mRNAs." Proc Natl Acad Sci USA 84(7): 1926-1930.

29. Read GS, Frenkel N (1983) “Herpes simplex virus mutants defective in the virion-associated shutoff of host polypeptide synthesis and exhibiting 
abnormal synthesis of $\alpha$ (immediate early) viral polypeptides." J Viro 46(2): 498-512.

30. Johnson RJ, Gretch DR, Yamabe H, Hart J, et al. (1993) "Membranoproliferative glomerulonephritis associated with hepatitis C virus infection." N Engl J Med 328(7): 465-470.

31. Choo QL, Kuo G, Weiner AJ, Overby LR, Bradley DW, et al. (1989) "Isolation of a cDNA clone derived from a blood-borne non-A, non-B viral hepatitis genome." Science 244(4902): 359-362.

32. Carrozzo M, Quadri R, Latorre P, Pentenero M, Paganin S, et al. (2002) et al "Molecular evidence that the hepatitis $\mathrm{C}$ virus replicates in the ora mucosa." Journal of Hepatology 37(3): 364-369.

33. Wang D, Liebowitz D, Kieff E (1985) "An EBV membrane protein expressed in immortalized lymphocytes transforms established rodent cells." Cell 43(3):831-840.

34. Mosialos G, Birkenbach M, Yalamanchili R, VanArsdale T, Ware C, et al (1995) "The Epstein-Barr virus transforming protein LMP1 engages signaling proteins for the tumor necrosis factor receptor family." Cell 80(3): 389-399.
35. Choo QL, Kuo G, Weiner AJ, Overby LR, Bradley DW, et al. (1989) "Isolation of a cDNA clone derived from a blood-borne non-A, non-B viral hepatitis genome". Science 244(4902): 359-362.

36. Miller WE, Cheshire JL, Baldwin AS, Raab Traub N (1998) "The NPC derived C15 LMP1 protein confers enhanced activation of NF-kappa B and induction of the EGFR in epithelial cells." Oncogene 16(14): 18691877.

37. AG Eliopoulos, Young LS (1998) "Activation of the cJun N-terminal kinase (JNK) pathway by the Epstein-Barr virus encoded latent membrane protein 1 (LMP1)". Oncogene 16(13): 1731-1742.

38. Eliopoulos AG, Gallagher NJ, Blake SMS, Dawson CW, Young LS (1999) "Activation of the p38 mitogen-activated protein kinase pathway by Epstein-Barr virus-encoded latent membrane protein 1 coregulates interleukin-6 and interleukin-8 production". Journal of Biological Chemistry 274(23): 16085-16096.

39. Zhang L, Pagano JS (2000) "Interferon regulatory factor 7 is induced by Epstein-Barr virus latent membrane protein 1". Journal of Virology74(3): 1061-1068.

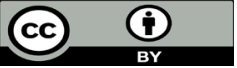

This work is licensed under Creative Commons Attribution 4.0 License

To Submit Your Article Click Here:

Submit Article

DOI: 10.32474/MADOHC.2019.03.000180

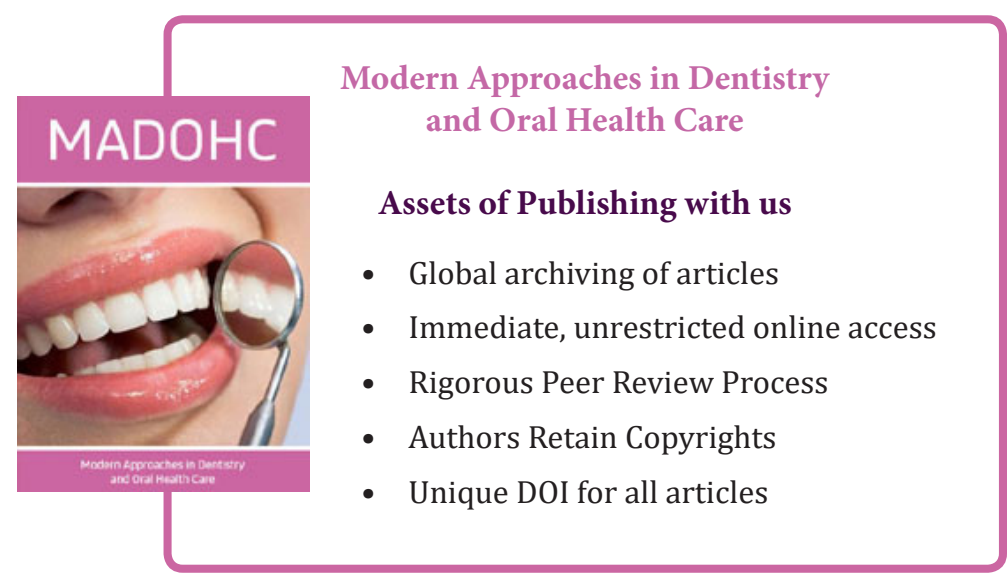

